\title{
PENENTUAN SATURATION NUMBER DARI GRAF BENZENOID
}

\author{
DARA RIFKA MAHZURA \\ Program Studi Matematika, \\ Fakultas Matematika dan Ilmu Pengetahuan Alam, Universitas Andalas, \\ Kampus UNAND Limau Manis Padang, Indonesia, \\ email : dmahzura@gmail.com
}

\begin{abstract}
Abstrak. Dalam makalah ini dibahas aplikasi graf dalam bidang ilmu kimia khususnya senyawa karbon benzenoid. Benzenoid adalah suatu senyawa yang tersusun atas atom karbon dan atom hidrogen. Benzenoid adalah termasuk dalam senyawa hidrokarbon, namun dikarenakan bentuknya yang unik maka benzenoid dikelompokkan sebagai suatu senyawa tersendiri. Graf Benzenoid ini berbentuk segienam beraturan. Titik-titik pada graf Benzenoid melambangkan atom karbon dan sisi-sisi pada graf Benzenoid melambangkan ikatan antar atom pada senyawa benzenoid. Saturation number pada graf $G$ adalah kardinalitas matching maksimal terkecil pada $G$. Pada makalah ini akan ditentukan saturation number pada beberapa graf Benzenoid.

Kata Kunci: Benzenoid, matching, matching maksimum, matching maksimal, perfect matching, saturation number, rantai Benzenoid
\end{abstract}

\section{Pendahuluan}

Teori matching adalah cabang dari teori graf yang berkaitan dengan kajian matching dalam aspek struktural dan aspek pencacahan. Matching adalah himpunan sisi pada suatu graf yang tidak saling berbagi titik. Perkembangan teori matching ini telah berpengaruh kuat dan menstimulir aplikasi kimia pada kajian model topological dari molekul-molekul yang mewakili senyawa konjuget. Adapun model topological yang dikaji adalah graf Benzenoid. Dalam skripsi ini akan dibahas struktur matching pada graf Benzenoid. Salah satunya adalah saturation number yang memberikan suatu informasi yaitu kemungkinan paling buruk kasus "penyumbatan" pada proses adsorpsi yang tidak efisien dalam senyawa benzenoid [5].

Suatu matching $M$ pada graf $G$ adalah himpunan sisi dari graf $G$ sedemikian sehingga tidak ada dua sisi dari $M$ yang saling berbagi titik. Kardinalitas $M$ disebut sebagai banyaknya sisi dari matching. Suatu titik $v$ disebut $M$-saturated jika ada sisi $M$ terkait (incidence) dengan $v$. Sebaliknya titik $u$ disebut $M$-unsaturated jika setiap sisi $M$ tidak terkait dengan $u$. $M$ adalah perfect matching jika setiap titik di $G$ adalah $M$-saturated.

Matching dengan kardinalitas kecil tidak menarik untuk dibahas, karena masingmasing sisi adalah matching dengan kardinalitas satu, dan himpunan kosong adalah matching dengan kardinalitas 0 . Oleh sebab itu, akan diselidiki kardinalitas matching sebesar mungkin. 
Suatu matching $M$ dikatakan matching maksimum jika tidak ada matching pada graf $G$ dengan kardinalitas yang lebih besar. Kardinalitas dari sebarang matching maksimum pada graf $G$ dilambangkan $v(G)$ dan disebut dengan banyaknya matching dari graf $G$. Karenanya, masing-masing titik dapat terkait dengan paling banyak satu sisi dari suatu matching. Ini berarti tidak ada graf dengan $n$ titik mempunyai kardinalitas matching lebih dari $\lfloor n / 2\rfloor$. Jika setiap titik dari $G$ terkait dengan sisi dari $M$, matching $M$ tersebut disebut perfect. Perfect matching disebut juga dengan matching maksimum, namun sebaliknya tidak berlaku. Kajian dari perfect matching terdapat pada struktur Kekule pada senyawa benzenoid yang mempunyai sejarah panjang dalam literatur matematika dan kimia [5].

Suatu matching $M$ adalah matching maksimal jika tidak dapat diperluas menjadi matching yang lebih besar pada $G$. Jelas bahwa masing-masing matching maksimum juga maksimal, tetapi untuk sebaliknya secara umum tidak benar.

Kardinalitas matching maksimal terkecil pada $G$ disebut sebagai saturation number pada graf $G$. Saturation number pada graf $G$ dilambangkan dengan $s(G)$. Saturation number pada suatu graf $G$ adalah paling sedikit setengah dari kardinalitas matching maksimum dari $G(v(G) / 2), s(G) \geq v(G) / 2[5]$.

Adapun tujuan dalam makalah ini adalah menentukan saturation number dari rantai Benzenoid dan mengkaji perilaku saturation number pada rantai Benzenoid dalam bidang ilmu kimia.

\section{Saturation Number pada Graf Benzenoid}

\subsection{Rantai Benzenoid}

Suatu sistem benzenoid adalah gabungan objek geometris yang diperoleh dari susunan heksagon reguler kongruen pada suatu bidang sehingga dua heksagon adalah terpisah atau mempunyai sisi bersama [9]. Suatu sistem benzenoid merupakan subhimpunan dengan 1-connected interior dari suatu ubin biasa pada bidang dengan bentuk segienam beraturan. Pada masing-masing sistem benzenoid, dapat membentuk suatu graf, dengan mengambil titik dari segienam sebagai titik, dan sisi dari segienam sebagai sisi graf. Dari definisi sederhana ini, bidang dan graf bipartid disebut sebagai graf Benzenoid [5].

Setiap permukaan dari suatu graf Benzenoid kecuali permukaan tak terhingga adalah heksagon. Titik yang terletak pada perbatasan permukaan non-heksagonal dari graf Benzenoid disebut titik eksternal, sedangkan untuk titik lain, jika ada, disebut sebagai titik internal. Suatu graf Benzenoid tanpa mempunyai titik internal disebut sebagai Catacondensed Benzenoid. Sedangkan jika suatu graf Benzenoid mempunyai titik internal disebut Pericondensed Benzenoid. Jika tidak ada heksagon pada Catacondensed Benzenoid yang berbatasan dengan tiga heksagon lainnya, ini disebut sebagai suatu rantai (chain). Pada masing-masing rantai Benzenoid, terdapat tepat dua heksagon yang berbatasan dengan heksagon satu sama lainnya, kedua heksagon itu disebut sebagai terminal, sedangkan heksagon lain disebut sebagai interior. Jumlah heksagon dari suatu rantai Benzenoid disebut panjang [5].

Suatu heksagon interior disebut straight jika dua sisinya saling berbagi dengan heksagon lain secara paralel, dan sebaliknya. Jika suatu heksagon yang sisi-sisi 
berbaginya tidak paralel, maka heksagon tersebut dikatakan kinky. Jika seluruh $h-2$ heksagon interior dari suatu rantai Benzenoid dengan $h$ heksagon maka dikatakan dengan straight, maka rantai ini dikatakan dengan polyacene, ditulis $A_{h}$. Jika setiap heksagon adalah kinky, maka rantai tersebut dikatakan polyphenancene, ditulis $Z_{h}$. Oleh karena itu, jumlah perfect matching pada $Z_{h}$ sama dengan bilangan Fibonacci ke $h+2$, yaitu $F_{(h+2)}$, polyphenancene juga disebut sebagai fibonacenes [5].

Perhatikan beberapa contoh graf Benzenoid pada Gambar 1. Keempat gambar tersebut merupakan suatu sistem benzenoid karena masing-masingnya adalah gabungan objek geometris yang diperoleh dari susunan heksagon reguler kongruen pada suatu bidang yang mempunyai sisi bersama. Gambar 1 pada bagian (A) mempunyai titik yang terletak pada perbatasan permukaan non-heksagonal yaitu titik eksternal dan titik yang terletak pada perbatasan permukaan heksagonal yaitu titik internal, sehingga disebut sebagai Pericondensed Benzenoid.

Gambar 1 pada bagian (B), (C) dan (D) hanya mempunyai titik eksternal, sehingga disebut sebagai Catacondensed Benzenoid. Selanjutnya Gambar 1 pada bagian (C) dan (D) disebut rantai karena tidak ada heksagon yang berbatasan dengan tiga heksagon lainnya. Heksagon straight terdapat pada Gambar 1 bagian (C) karena ada heksagon interior yang memiliki sisi berbagi saling paralel. Sedangkan heksagon kinky terdapat pada gambar (D) yang sisi-sisi berbagi graf Benzenoid tidak paralel. Jelas bahwa rantai polyacene ditunjukkan pada Gambar 1 bagian (C), disimbolkan sebagai $A_{5}$ yaitu rantai polyacene dengan 5 heksagon. Sebaliknya rantai polyphenancene ditunjukkan pada Gambar 1 bagian (D), disimbolkan sebagai $Z_{6}$ yaitu rantai polyphenancene dengan 6 heksagon.

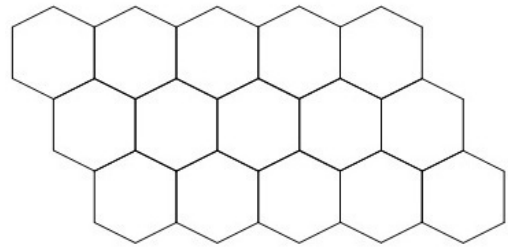

(A)<smiles>C1CCC2CC3CC4CC5C(CC4CC3CC2C1)CC1CCCCC15</smiles>

(c)

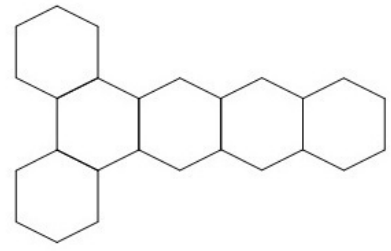

(B)

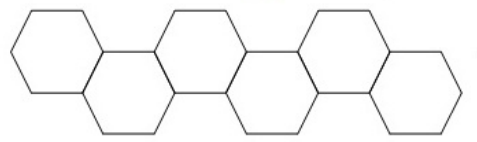

(D)

Gambar 1. Beberapa contoh graf Benzenoid

\subsection{Penentuan Saturation Number pada Graf Benzenoid}

Proposisi-proposisi berikut memberikan informasi saturation number pada rantai Benzenoid. 
Proposisi 2.1. [5] Misalkan $B_{h}$ adalah suatu rantai Benzenoid dengan h heksagon, $\operatorname{maka} s\left(B_{h}\right) \geq h+1$.

Bukti. Jelas bahwa rantai dari $B_{h}$ mempunyai titik sebanyak $4 h+2$. Karena $B_{h}$ mempunyai perfect matching, jumlah matching ini adalah $2 h+1$. Oleh karena itu $s(G) \geq(2 h+1) / 2$ dan karena $s(G)$ bilangan bulat, maka $s(G) \geq h+1$.

Proposisi 2.2. [5] $s\left(B_{h}\right)+1 \leq s\left(B_{h+1}\right) \leq s\left(B_{h}\right)+2$.

Bukti. Misalkan $s\left(B_{h+1}\right) \leq s\left(B_{h}\right)$ dan $M$ adalah matching maksimal pada $B_{h+1}$ dengan kardinalitas $s\left(B_{h+1}\right)$. Misal diberikan label heksagon $B_{h+1}$ adalah $H_{1}, H_{2}, \cdots, H_{h+1}$, maka $H_{h+1}$ memuat paling sedikit satu sisi di $M$ sedemikian sehingga tidak ada titik-titik ujungnya yang saling terkait dengan sisi di $H_{h}$. Misal sisi $e=u v . M-e$ matching maksimal pada $B_{h+1} \backslash\{e\}=B_{h+1} \backslash\{u v\}$. Jika setiap sisi $M-e$ juga sisi di $B_{h}$, maka diperoleh matching maksimal di $B_{h}$ dengan kardinalitas kurang dari $s\left(B_{h}\right)$ adalah kontradiksi. Oleh karena itu, harus ada suatu sisi $e^{\prime}$ di $M-e$ dengan satu titik ujung (sebut $u^{\prime}$ ) pada $B_{h}$ dan titik lain (sebut $\left.v^{\prime}\right)$ pada $B_{h+1} \backslash B_{h}$. Hapus $e^{\prime}$. Jika sisanya adalah matching maksimal di $B_{h}$, maka terdapat kontradiksi. Jika menghapus $e^{\prime}$, tersisa pasangan titik unsaturated bertetangga $\left\{u^{\prime}, w^{\prime}\right\}$ di $B_{h}$ dengan unsaturating $u^{\prime}$. Selanjutnya perluas $M-e-e^{\prime}$ dengan $u^{\prime} w^{\prime}$. Matching maksimal di $B_{h}$ dengan kardinalitasnya kurang dari $s\left(B_{h}\right)$, lagi-lagi merupakan kontradiksi. Oleh karena itu $s\left(B_{h+1}\right)>s\left(B_{h}\right)$, sehingga paling sedikit $s\left(B_{h+1}\right) \geq s\left(B_{h}\right)+1$.

Proposisi 2.3. [5] $s\left(B_{h}\right)=h+1$ jika dan hanya jika $B_{h}=A_{h}$.

Bukti. $(\Leftarrow)$ Setiap sisi titik $A_{h}$ membentuk matching maksimal dengan $s\left(A_{h}\right) \leq$ $h+1$. Dengan menggunakan Proposisi 2.1, karena $s\left(A_{h}\right) \geq h+1$, maka diperoleh $s\left(A_{h}\right)=h+1$.

$(\Rightarrow)$ Misalkan $s\left(B_{h}\right)=h+1$. Terdapat $4 h+2$ titik pada $B_{h}$ dan $2 h+2$ titik adalah saturated dengan kardinalitas matching maksimal $M$ adalah $h+1$. Sehingga menyisakan $2 h$ titik terkait dengan $4 h$ sisi yang tidak dalam $M$. Karena tidak ada titik berderajat satu, masing-masing titik unsaturated harus terkait dengan tepat dua sisi bukan $M$. Selanjutnya tidak ada heksagon yang tidak membuat tiga titik unsaturated. Oleh karena itu tiap heksagon memuat dua titik unsaturated berderajat 2 yang tidak bertetangga. Hal ini hanya dimungkinkan untuk $A_{h}$.

Proposisi 2.4. [5] $s\left(B_{h, 1}\right)=h+2$.

Bukti. Rantai Benzenoid $B_{h, 1}$ mempunyai $k+m$ heksagon. Matching $M$ memuat $k+m-1$ sisi yang saling berbagi, satu sisi pararel dengan sisi yang saling berbagi pada masing-masing heksagon terminal, dan satu sisi yang terhubung dengan dua titik berderajat 2 pada heksagon kinky. Jumlah sisi-sisi tersebut jelas maksimal. Oleh karena itu $s\left(B_{h, 1}\right) \leq k+m+2$. Dengan menggunakan Proposisi 2.2, $s\left(B_{h, 1}\right)$ harus melebihi $s\left(A_{h}\right)=k+m+1$, yaitu $s\left(B_{h, 1}\right) \geq k+m+2=h+2$. Jadi, $s\left(B_{h, 1}\right)=k+m+2=h+2$. 
Proposisi 2.5. [5] Misal $B_{h, k}$ adalah Rantai Benzenoid dengan panjang $h$ dengan $k$ heksagon kinky sedemikian sehingga tidak ada dua heksagon kinky yang bertetangga. Maka $s\left(B_{h, k}\right)=h+k+1$.

Bukti. Proposisi 2.4 adalah peluasan kasus dari Proposisi 2.3. Karena $s\left(B_{h, 1}\right)=$ $h+2$, dan $B_{h, 1}$ memuat satu heksagon kinky, maka $s\left(B_{h, 1}\right)$ dapat ditulis dalam bentuk lain yaitu $s\left(B_{h, 1}\right)=(h+1)+1$. Akibatnya $B_{h, k}$ yang memuat $k$ heksagon kinky sedemikian sehingga tidak ada dua heksagon yang bertetangga mempunyai $s\left(B_{h, k}\right)=h+k+1$.

Proposisi 2.6. [5] Misal $Z_{h}$ adalah fibbonacene dengan panjang h. Maka $s\left(Z_{h}\right)=$ $\left\lfloor\frac{4 h}{3}\right\rfloor+1$.

Bukti. Berdasarkan Proposisi 2.2, tidak ada matching maksimal yang kardinalitasnya 4 pada $Z_{3}$. Oleh karena itu untuk sebarang tiga heksagon kinky yang berurutan dalam suatu rantai mempunyai paling sedikit 4 saturation numbernya. Disisi lain, dua heksagon kinky yang berurutan dapat selalu ditambahkan ke $B_{h}$ pada satu sisi di masing-masing heksagon kinky. Ini menunjukkan bahwa tiga heksagon kinky yang berurutan tidak mengharuskan lebih dari 4 sisi yang baru. Formula eksak mengikuti pencocokan bentuk umum saturation number pada fibonacene pendek. $\square$

\section{Kesimpulan}

Pada makalah ini telah ditentukan saturation number pada rantai Benzenoid serta telah dikaji perilaku saturation number pada beberapa bentuk rantai Benzenoid.

\section{Ucapan Terima kasih}

Penulis mengucapkan terima kasih kepada Bapak Prof. Dr. Syafrizal Sy, Ibu Dr. Lyra Yulianti, Bapak Dr. Mahdhivan Syafwan, Bapak Dr. Admi Nazra, Bapak Narwen, M.Si, yang telah memberikan masukan dan saran sehingga makalah ini dapat diselesaikan dengan baik.

\section{Daftar Pustaka}

[1] Alexandru T. Balaban. 1985. Applications of Graph Theory in Chemistry. Journal of Chemical Information and Computer Sciences. 25: $334-343$.

[2] Benko, Gill, Cristoph Flamn, dan Peter F Stadles. 2003. A Graph-Based Toy Model of Chemistry. Journal of Chemical Information and Computer Sciences. 43:1085-1093.

[3] Bondy, J. A. dan U. S. R. Murty. 1976. Graph Theory with Applications. Macmillan, London.

[4] Diestel, Reihhad. 2005. Graph Theory. Electric Edition. Springer-Verlag Hidelberg, New York.

[5] Doslic, Tomislav dan Irane Zubac. 2015. Saturation Number of Benzenoid Graph. MATCH Communications in Mathematical and in Computer Chemistry. 73: $491-500$. 
46 Dara Rifka Mahzura

[6] Hartsfield, Nora dan Gerhard Ringel. 1990. Pearls in Graph Theory: A Comprehensive Introduction. Academic Press Limited, London.

[7] Meifiani, Nely Indra. Aplikasi Cayley Tree dalam Menentukan Banyak Isomer Senyawa Alkana. Skripsi S-1. Tidak diterbitkan.

[8] N.L. Biggs, R.J. Lloyd dan R.J. Wilson. 1986. Graph Theory 1736-1936. Clarendon Press, Oxford.

[9] S. J. Cyvin dan I. Gutman. 1988. Kekulé Structures in Benzenoid Hydrocarbons. Springer, Berlin. 